The Rediscovery of the Queen of Eciton (Labidus) coecum Latr. (Hym.: Formicidae)

\author{
NEAL A. WEBER
}

Reprinted from

"THE AMERICAN MIDLAND NATURALIST"

Vol. 26, No. 2, pp. 325-329, September, $1941 d$ 


\title{
The Rediscovery of the Queen of Eciton (Labidus) coecum Latr. (Hym.: Formicidae)
}

\author{
Neal A. Weber
}

Of all the notorious army ants in the New World the most widely ranging species is Eciton (Labidus) coecum Latr. This ant is recorded from many localities in Texas and is common in Mexico, Central America and South America to Argentina, a range which very few species of ants have. It is found in the tropical countries in cultivations and around habitations so that it is an insect generally known to the natives. Though seen so often it is remarkable that the only queen known to science was one described in 1885 by André from a collection made in Mexico ${ }^{1}$ until Dr. Carlos Bruch published in $1934^{2}$ the description of a female from Argentina. In the latter important work Dr. Bruch mentioned the possibility of the female belonging to $L$. coecum var. jurinei Shuckard which was described from males from Brazil.

Described below is a third female of this species from British Guiana which is not only interesting because of the rarity of this caste but because it may well belong to the typical form. The differences between it and the Argentine specimen, as described below, are sufficiently marked to indicate that they belong to different subspecies. The figures of the Guiana female supplement the small sketches of the Mexican ant published in 1885. The latter sketches are not sufficiently clear for detailed comparisons but the two ants are obvious. ly conspecific. The queens, incidentally, show much more distinct differences than do the corresponding soldier and worker castes. The Mexican female was received by André from a collection made by $\mathrm{M}$. Lichenstein without further biological information and the Argentine ant was sent Dr. Bruch by an engireer. This ant was taken by a peon and there is also no information published on the bivouac in which it was found.

The British Guiana female was taken by myself from a bivouac found in 1936. Pressure of other work has prevented the publishing of this record until the present time but in the intervening five years no other females of this species have been recorded.

The locality of the bivouac was high, virgin rain forest along the Oko River, a short tributary of the Mazaruni River about 20 miles west of Bartica. June 24,1936 , I picked up from a rotted tree stump what I took at first to be a peculiar looking soldier Pheidole. Upon hacking into the rotted wood of the stump with a cutlass ants of several sizes were found and their motions gave them away as army ants without the necessity of examination through a lens.

1 André, E. 1885. Supplement au species des Formicides d'Europe et des pays limitrophes. Species des Hyménoptères, 8:838-840, figs. 1-5.

2 Bruch. C. 1934. Las formas femeninas de Eciton. Descripcion y redescripcion de algunas especies de la Argentina. Anal. Soc. Cient. Argentina 118:113-135. 
Further cutting showed that this was the top of a bivouac and that the wood was pierced in all directions by tunnels filled with the ants, some with larvae and cocoons of workers. The tree stump was 3.5 meters high, $55 \mathrm{~cm}$. in diamcter at the base and $38 \mathrm{~cm}$. in diameter at the top. It was exposed to the sun on all sides except for a little shade during the afternoon from the southwest. The part of the stump occupied by the ant bivouac was the basal $150 \mathrm{~cm}$. Immediately above the bivouac in the stump was a carton nest of the termite, Neocapritermes angusticeps Emerson (det. Dr. Emerson). Some of the ants were found in the lower part of the termite nest and in tunnels in the wood surrounding it. In the wood above the bivouac were three additional termite species, Convexitermes mazaruniensis Emerson, Nasutitermes gaigei Emerson, and Neocapritermes bodkini (Silvestri) (det. Dr. Emerson), the latter species being represented by a single dealate found in an earth carton nest containing the Convexitermes. Probably the termites afforded the carnivorous ants some food but the raiding columns would doubtless bring in far more food from the sutrounding forest. 3 The stump was completely demolished with an axe. In the tunnels just above the soil level eggs and very young larvae were taken. Finally, at the bottom of the stump just below the soil level the queen was found surrounded by a mass of seething workers. They were removed with difficulty. Though distended with eggs she could crawl slowly but could not right herself if placed on her back. She was photographed while alive in the palm of an Arawak Indian who assisted me.4 With a number of small workers clustered about her she was kept alive in a small container and laid so many eggs June 24 and 25 that the gaster returned to its contracted state. June 26 in the morning she was dead though most of the workers with her were alive and active. This experience with the short life in captivity of the queen duplicates my experience in Trinidad, B. W. I., with a queen of Eciton (Eciton) burchelli urichi Forel. Ordinarily queen of ants in general are longer lived and tougher than workers but the reverse seems true in army ants.

In addition to the four species of termites there were other arthropods in

Photograph of the female, while alive and distended with eggs.

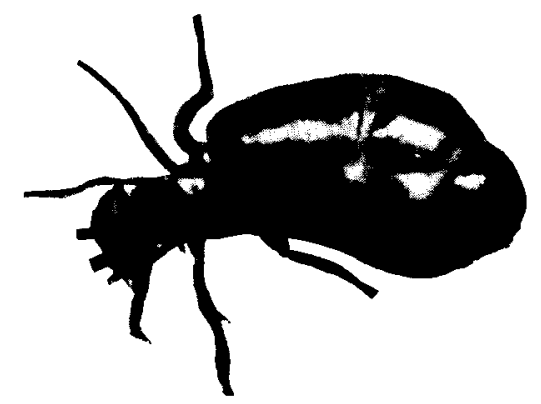

3 As an illustration of their carnivorous habit, Mr. F. A. Squire sent me specimens of this species for determination, taken in Georgetown, B. Guiana 8.vii. 1935, which had killed 22 young chickens.

4 This photograph was published in Turtox News, General Biological Supply House, Chicago, 1938, 16(1):24. 
the stump. A medium-sized black and a small scorpion, spiders, millipedes, a huge beetle larva (probably a longicorn), staphylinid and other beetles, and the following ants were present: Pachycondyla crassinoda, Euponera (Mesoponera) sp. (probably constricta Mayr), Crematogaster, Pheidole, a tiny yellow Solenopsis, Sericomyrmex, and Nylanderia.

Living with the army ants was a tiny dimorphic ant-like myrmecophile resembling in general the figure of Pulicomorpha coecum Mann,,$^{5}$ an anoma-
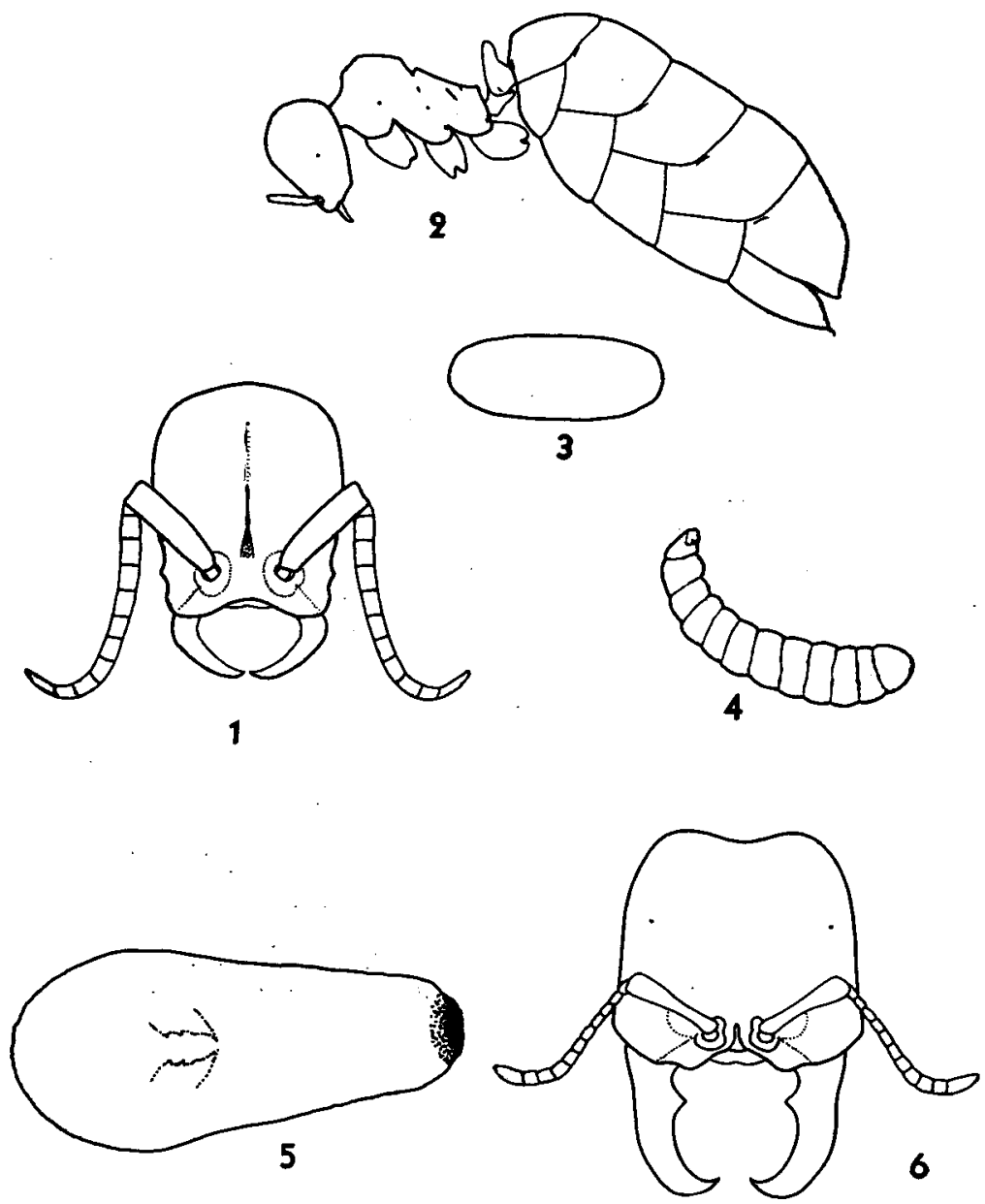

Figs. 1-6. Eciton (Labidus) coecum Latr., British Guiana Colony, N. A. Weber. 1. Head of female in frontal view. 2. Body outline in side view of female. 3. Egg laid by female. 4. Medium larva, showing outline of body. 5. Worker pupa, showing scleritized mandibles within cocoon. 6 . Head of soldier in frontal view. 
lous blind Aleocharine staphylinid beetle. This latter beetle was taken with a cluster of Eciton peninsularis Mann in Lower California. There were in the Guiana bivouac several additional myrmecophiles.

The British Guiana female differs from Dr. Bruch's figure of the Argentire female especially as follows: Size smaller; head more elongate; clypeal margin anteriorly concave, not truncate; antennal scapes longer; thorax in side view more sharply angulate, from above the pronotum is produced as hemispherical lobes instead of rounded obtuse angularities, the middle of thorax more contricted and the epinotum has quite different proportions; petiolar lobes narrower. These numerous differences are so distinct as to indicate at least subspecific differences. The general structure, however, is the same and very unlike that of females of Eciton (Eciton) burchelli or hamatum.

Although André's figures are small and poorly drawn there is a general resemblance between them and the corresponding parts of the British Guiana female. Andre's figures show the rotundity of the head, the falcate mandibles, the short antennal segments, the constriction between the thorax and the epinotum as well as the lowered epinotum, the bidentate petiole and the distended gaster.

A formal description supplementing the figures follows.

\section{ECITON (LABIDUS) COECUM Latr.}

Female (Figs. 1 and 2). Length as shown in figure $17 \mathrm{~mm}$., of length when living and distended with eggs about $21 \mathrm{~mm}$., of gaster when contracted as in figure $12.5 \mathrm{~mm}$., maximum length of thorax from apex of pronotum to episternal angle $4.2 \mathrm{~mm}$. Thorax strongly constricted in the middle, from above $2.0 \mathrm{~mm}$. broad through pronotum, $1.14 \mathrm{~mm}$. broad through mesosternal region. $2.1 \mathrm{~mm}$. broad through epinotum; middle of thorax produced dorsally as a rounded ridge. Petiole produced in two diverging lobes whose apices are 2.9 mm. apart, the depression between evenly convex. First gastric segment from above truncate anteriorly and terminating laterally as a rounded tubercle on each side. Femora and tibiae laterally compressed.

Head closely and deeply pitted between which the surface is finely punctate. Similarly pitted on the thorax and petiole but more widely spaced and confined largely to the dorsal or protruding surfaces, similarly punctate. Gaster with faint large pits and microscopic fine, dense and shallow punctations. Appendages including mandibles finely punctate with scattered shallow pits.

Pilosity of sparse, short fine hairs at sutures and a reclinate pubescence on the appendages which is thickest on the antennae and tarsi.

Color an even dull ferruginous, gastric segments brown with paler brown margins.

Worker. Length $3-11 \mathrm{~mm}$., the maxima being a distinct soldier caste (Fig. 6). Thorax length 0.86-3.52 $\mathrm{mm}$., this structure being capable of more precise

5 Mann, W. M., 1924. Myrmecophiles from the Western United States and Lower California. Ann. Ent. Soc. Amer. 17:87-95, Figs. 1, 2. 
measurement than the whole body. 125 workers were taken at random from the collection and the above measurements made. The largest number (20) were $6 \mathrm{~mm}$. long and the second largest number (16) were $4.5 \mathrm{~mm}$. in length. The thorax length of the largest number (15) was $2.2 \mathrm{~mm}$.

Brood. Eggs (Fig. 3) elliptical, white, $0.44 \times 0.19 \mathrm{~mm}$. Larvae (Fig. 4) slender, curved, with numerous fine, simple hairs. Worker pupae (Fig. 5) ovate-elliptical, enclosed in whitish cocoons and with head end enlarged.

\section{Other Ecrion females}

Three new records of Eciton females are the following:

On Barro Colorado Island, Panama Canal Zone June 11, 1938, Dr. T. C. Schneirla and myself took from a bivouac a female of Eciton (E.) hamatum (Fabr.). In alcohol she is distinctly paler and smaller than the following, being about $19 \mathrm{~mm}$. long with a thorax length of $5.3 \mathrm{~mm}$. and having eyes $0.19 \mathrm{~mm}$. in diameter.

Eciton (E.) burchelli urichi Forel is common in Trinidad, B.W.I. The female, however, is unrecorded in the literature. July 4, 1935, I found a bivouac in the foothills immediately north of Tunapuna in Trinidad.from which I secured the female. Freshly chloroformed the ant was about $21 \mathrm{~mm}$. long with the gaster $11 \mathrm{~mm}$. long and $6 \mathrm{~mm}$. broad. In alcohol the thorax length is $4.9 \mathrm{~mm}$. and the eyes $0.24 \mathrm{~mm}$. in diameter. Compared with Wheeler's figures of the typical female from Kartabo, British Guiana, ${ }^{6}$ it differs chiefly in having larger eyes and shorter petiolar lobes.

Near where the Oronoque River joins the New River in about Lat. $2^{\circ} 42^{\prime}$ $\mathrm{N}$. in British Guiana I found an Eciton bivouac July 21, 1936. The bivouac was at the base of a tree stump close to a giant Brazil nut tree in virgin rain forest. The female was taken and in alcohol measures about $21 \mathrm{~mm}$. long with a thorax length of $4.9 \mathrm{~mm}$. and eyes $0.21 \mathrm{~mm}$. in diameter. Workers, soldiers and the female obviously belong to the species burchelli. The latter specimen, however, has the mandibles distinctly less sharply curved apically than the Trinidad or Kartabo ants and has much longer petiolar lobes than the Trinidad form. The Trinidad female has much more abundant and stouter hairs. These and other differences indicate that the Oronoque burchelli belongs to a new subspecies for which the name jeanae is here proposed.

6 Wheeler, W. M., 1921. Observations on army ants in British Guiana. Proc. Amer. Acad. Arts \& Sc. 56:291-328, 10 figs.

University of North Dakota,

Grand Forks, N. Dak. 